\title{
Protein Synthesis during Recovery of Tellurite Resistance by Heat-injured Streptococcus faecalis
}

\author{
By JENNIFER M. GEE AND J. PAYNE \\ Agricultural Research Council, Food Research Institute, Colney Lane, \\ Norwich NR4 $7 U A$
}

(Received 10 November 1978)

INTRODUCTION

Payne \& Morley (1976) have shown that cells of Streptococcus faecalis heated at $60{ }^{\circ} \mathrm{C}$ rapidly lose resistance to potassium tellurite. Recovery of tellurite resistance occurred on subsequent incubation in heart infusion broth at $33^{\circ} \mathrm{C}$ and was dependent on protein synthesis. Several organisms, including Salmonella typhimurium, Staphylococcus aureus S6 and Vibrio parahaemolyticus, require protein synthesis to recover from sub-lethal heating (Tomlins \& Ordal, 1971; Hurst et al., 1973; Emswiler et al., 1976; Gomez et al., 1976). However, little information is available on the extent of such protein synthesis and whether this involves many or only a few specific proteins.

Recently it has been shown that heat-injured $S$. faecalis can recover tellurite resistance in a semi-defined medium that does not support growth (Payne, 1978). This recovery system has now been used to investigate further the extent and range of proteins synthesized during recovery of tellurite resistance by heat-injured $S$. faecalis.

\section{METHODS}

Maintenance and culture of organisms. Cultures of Streptococcus faecalis var. liquefaciens EB/F/30/39 were maintained and grown as previously described (Payne \& Morley, 1976). For isotope dilution experiments the cells were grown in medium containing $\mathrm{L}-\left[\mathrm{U}_{-}{ }^{14} \mathrm{C}\right]$ valine at $0.02 \mu \mathrm{Ci} \mathrm{ml}^{-1}$. This amino acid was used to ensure that ${ }^{14} \mathrm{C}$ was only incorporated into protein.

Heat-injury and recovery procedure. These procedures were as previously described when cells were heated for $4 \mathrm{~min}$ at $60^{\circ} \mathrm{C}$ at densities of about $1 \times 10^{9}$ viable units $\mathrm{ml}^{-1}$ (Payne, 1978), except that cells were washed with $100 \mathrm{~mm}-\mathrm{K}_{2} \mathrm{HPO}_{4} / \mathrm{KH}_{2} \mathrm{PO}_{4}$ buffer, $\mathrm{pH} 7 \cdot 1$. Washed cell pellets of unheated, heated, and heated cells incubated in recovery medium were stored at $-20^{\circ} \mathrm{C}$ prior to extraction and assay.

In experiments to follow the incorporation of ${ }^{14} \mathrm{C}$-labelled amino acids into protein synthesized during recovery from heat-injury, $\mathrm{L}-\left[\mathrm{U}-{ }_{-14} \mathrm{C}\right]$ aspartate was used since preliminary experiments had shown that at least $60 \%$ of the aspartic acid content of the recovery medium was utilized during the recovery period. Although valine utilization was not so great, $\mathrm{L}_{-}\left[\mathrm{U}_{-}{ }^{14} \mathrm{C}\right]$ valine was used in confirmation experiments. Radioactive amino acid was added to the recovery medium at a final concentration of $0.02 \mu \mathrm{Ci} \mathrm{ml}^{-1}$.

In some experiments chloramphenicol, at a final concentration of $100 \mu \mathrm{g} \mathrm{ml}^{-1}$, was added to the recovery medium to inhibit protein synthesis.

Viable counts. These were carried out as previously described (Payne \& Morley, 1976).

Extraction and estimation of total cell protein. Protein was extracted from washed cells using a modification of the method of Schneider (1945). Cells were first extracted with $5 \mathrm{ml} 5 \%$ (w/v) trichloroacetic acid (TCA) for $15 \mathrm{~min}$ at 0 to $2{ }^{\circ} \mathrm{C}$, centrifuged and the supernatant was discarded. The pellet was further extracted with $5 \mathrm{ml} 5 \%(\mathrm{w} / \mathrm{v}) \mathrm{TCA}$ for $15 \mathrm{~min}$ at $90^{\circ} \mathrm{C}$, centrifuged and the supernatant was discarded. Protein in the pellet material was solubilized by heating for $5 \mathrm{~min}$ at $100^{\circ} \mathrm{C}$ with $3 \mathrm{ml} 1 \mathrm{M}-\mathrm{NaOH}$. Duplicate $0 \cdot 1 \mathrm{ml}$ samples of the protein solution were removed for determination of radioactivity and the remainder was assayed for protein by a modification of the biuret method (Herbert et al., 1971).

Preparation of cell-free extracts. Washed cell pellets were resuspended in $2.5 \mathrm{ml} 100 \mathrm{mM}-\mathrm{K}_{2} \mathrm{HPO}_{4} / \mathrm{KH}_{2} \mathrm{PO}_{4}$ buffer, $\mathrm{pH} 7 \cdot 1$, with $3 \mathrm{~g}$ glass beads $(0.11 \mathrm{~mm}$ diam.). This suspension was shaken on a Mickle disintegrator (Mickle Laboratory Engineering Co., Guildford), tuned to maximum amplitude, for $15 \mathrm{~min}$ at $1{ }^{\circ} \mathrm{C}$, followed 
by low-speed centrifugation $\left(2000 \mathrm{~g}, 10 \mathrm{~min}, 2^{\circ} \mathrm{C}\right.$ ) to remove the glass beads and then high-speed centrifugation $\left(25000 \mathrm{~g}, 10 \mathrm{~min}, 2^{\circ} \mathrm{C}\right)$ to remove cell debris. The clear supernatant was dialysed against $100 \mathrm{~mm}$ $\mathrm{K}_{2} \mathrm{HPO}_{4} / \mathrm{KH}_{2} \mathrm{PO}_{4}$ buffer, $\mathrm{pH} 7 \cdot 1$, for $16 \mathrm{~h}$ at $1{ }^{\circ} \mathrm{C}$ and used immediately for polyacrylamide gel electrophoresis. Protein was assayed by the method of Lowry et al. (1951).

Polyacrylamide gel electrophoresis. Disc gel electrophoresis was based on the method of Davis \& Ornstein (1961) at pH 8.5 with $7.5 \%(\mathrm{w} / \mathrm{v})$ acrylamide. Volumes of cell-free extract (containing $200 \mu \mathrm{g}$ protein) were applied to gels with $0.05 \mathrm{ml}$ bromophenol blue $(0.001 \%, \mathrm{w} / \mathrm{v})$ as marker. Electrophoresis was carried out at $1{ }^{\circ} \mathrm{C}$ with a current of $5 \mathrm{~mA}$ per tube until the marker had travelled the length of the gel. Gels were stained with $1 \%(\mathrm{w} / \mathrm{v})$ amido black in $7 \%(\mathrm{v} / \mathrm{v})$ acetic acid and destained by washing repeatedly with $7 \%$ acetic acid. Densitometer profiles of the stained gels were recorded with a Chromoscan (Joyce-Loebl, Gateshead, Tyne $\&$ Wear). The gels containing radioactive protein were subsequently sliced into $1 \mathrm{~mm}$ discs using a Mickle gel slicer and the discs were dried and prepared for radioactive counting by the method of Goodman \& Matzura (1971).

Measurement of radioactivity. Radioactive protein, in $\mathrm{NaOH}$ solution $(0 \cdot 1 \mathrm{ml})$ or in dissolved gel slices, was counted in polypropylene counting vials (Packard) after adding $10 \mathrm{ml}$ scintillator [toluene/Triton $\mathrm{X}-100 /$ water $(6: 3: 1$, by vol.) containing $0.6 \%$ (w/v) 2,5-diphenyloxazole]. Samples were allowed to stabilize in the dark at $17^{\circ} \mathrm{C}$ for at least $4 \mathrm{~h}$ prior to counting radioactivity in a Philips model PW4510 liquid scintillation spectrometer. Counting efficiency was determined by a channels ratio technique calibrated with standard $\left[{ }^{14} \mathrm{C}\right]$ hexadecane, taking into account any quenching of the samples, and was about $70 \%$ and $50 \%$ for ${ }^{14} \mathrm{C}$ in protein in $\mathrm{NaOH}$ solution and dissolved gel slices, respectively. The observed count was corrected for background and efficiency and expressed as d.p.m.

The proportion of cellular protein synthesized during recovery was calculated from the extent of isotope dilution using the formula:

Protein synthesized during recovery as a percentage of the total cell protein at the end of recovery

$$
=100-\frac{\text { (specific activity of protein from recovered cells) }}{\text { (specific activity of protein from heated cells) }} \times 100
$$

\section{RESULTS AND DISCUSSION}

\section{Effect of chloramphenicol on recovery}

When heat-injured cells of $S$. faecalis, which had lost resistance to potassium tellurite, were incubated for $6 \mathrm{~h}$ in the standard recovery medium that did not permit growth, at least $70 \%$ of injured cells recovered (Payne, 1978). When chloramphenicol was added to this medium less than $20 \%$ of the cells recovered. Examination of polyacrylamide gels did not reveal any differences between proteins extracted from heat-injured cells incubated in recovery medium with or without chloramphenicol.

Isotope dilution experiments showed that in the presence of chloramphenicol the amount of new protein synthesis (Table 1, expts 2, 5 and 6) was not significant within the limitations of the method. However, this does not preclude the suggestion that in the presence of the antibiotic there might have been a small amount of protein synthesis which was sufficient to account for the recovery of tellurite resistance by a small proportion of the heat-injured cells.

\section{Extent of protein synthesis during recovery}

In isotope dilution experiments the specific radioactivities of the protein fraction from cells grown in the presence of $\mathrm{L}-\left[\mathrm{U}-{ }^{14} \mathrm{C}\right]$ valine were similar for both heated and unheated cells (Table 1, expts 3, 4 and 5). Protein extracted from heated cells incubated in recovery medium for $6 \mathrm{~h}$ had a lower specific radioactivity which corresponded to about $40 \%$ of the cell protein being synthesized during recovery. Unheated cells incubated under similar conditions appeared to have synthesized at least $50 \%$ new protein (Table 1, expts 1 and 2).

Since the heat-injured cells were recovered in a medium that did not support growth and were therefore not dividing, experiments were carried out to determine if the protein synthesis resulted in an increase in cellular protein. Comparison of the cellular protein content, on a dry wt or total cell number basis, showed no net increase during the $6 \mathrm{~h}$ recovery 
Table 1. Isotope dilution of radioactive protein during recovery of tellurite resistance by heat-injured $S$. faecalis

Cells were grown in heart infusion broth containing $\mathrm{L}-\left[\mathrm{U}-{ }^{14} \mathrm{C}\right]$ valine, heated for $4 \mathrm{~min}$ at $60^{\circ} \mathrm{C}$ and incubated in semi-defined recovery medium at $33^{\circ} \mathrm{C}$ for $6 \mathrm{~h}$. Total protein was extracted from samples of unheated, heated and recovered cells and the specific radioactivity was determined.

\begin{tabular}{|c|c|c|c|c|c|c|}
\hline \multirow[b]{2}{*}{ Expt } & \multicolumn{6}{|c|}{ Specific radioactivity of protein \pm s.E. (d.p.m. $\mathrm{mg}^{-1}$ ) } \\
\hline & $\begin{array}{l}\text { Unheated } \\
\text { cells }\end{array}$ & $\begin{array}{l}\text { Unheated } \\
\text { cells } \\
\text { incubated in } \\
\text { recovery } \\
\text { medium }\end{array}$ & $\begin{array}{l}\text { Unheated } \\
\text { cells } \\
\text { incubated in } \\
\text { recovery } \\
\text { medium } \\
\text { + chloram- } \\
\text { phenicol }\end{array}$ & Heated cells & $\begin{array}{l}\text { Heated cells } \\
\text { incubated in } \\
\text { recovery } \\
\text { medium }\end{array}$ & $\begin{array}{l}\text { Heated cells } \\
\text { incubated in } \\
\text { recovery } \\
\text { medium } \\
\text { + chloram- } \\
\text { phenicol }\end{array}$ \\
\hline $\begin{array}{l}1 \\
2\end{array}$ & $\begin{array}{l}26860 \pm 800 \\
21129 \pm 369\end{array}$ & $\begin{array}{r}12212 \pm 508 \\
4954+173\end{array}$ & $20333+648$ & 二 & 二 & - \\
\hline 3 & $27175 \pm 762$ & 二 & - & $27765 \pm 802$ & $18252 \pm 773$ & - \\
\hline 4 & $29030 \pm 943$ & - & - & $26016 \pm 899$ & $14663 \pm 543$ & 一 \\
\hline 5 & $21880 \pm 325$ & 一 & 一 & $22912 \pm 418$ & $11003 \pm 315$ & $21952 \pm 734$ \\
\hline 6 & 二 & - & - & $17128 \pm 477$ & $10407 \pm 351$ & $15650 \pm 481$ \\
\hline
\end{tabular}

period $\left[0.40 \mathrm{mg}\right.$ protein $(\mathrm{mg} \text { dry } \mathrm{wt})^{-1}$ and $0.34 \mathrm{mg}$ protein $(\mathrm{mg} \text { dry } \mathrm{wt})^{-1}$ for heated and recovered cells, respectively] indicating that protein synthesis was balanced by at least an equivalent amount of degradation, and therefore represented turnover. With non-growing cultures of Escherichia coli, Mandelstam (1958) estimated a cellular protein turnover rate of $5 \% \mathrm{~h}^{-1}$, while Pine (1965) concluded that the value was $20 \% \mathrm{~h}^{-1}$. Our data for $S$. faecalis indicate turnover rates of about $6 \% \mathrm{~h}^{-1}$ and $12 \% \mathrm{~h}^{-1}$ for heated and unheated cells, respectively.

\section{Incorporation of ${ }^{14} \mathrm{C}$ into protein during recovery}

Polyacrylamide gel electrophoresis of the soluble proteins extracted from heat-injured cells after incubation in recovery medium containing $\mathrm{L}-\left[\mathrm{U}-{ }^{14} \mathrm{C}\right]$ aspartate showed that the recovery of tellurite resistance was accompanied by the incorporation of ${ }^{14} \mathrm{C}$ into all the soluble protein bands. The profiles were similar to those obtained when unheated cells were incubated under similar conditions. Recovery experiments in which L- $\left[\mathrm{U}-{ }^{14} \mathrm{C}\right]$ valine replaced L- $\left[\mathrm{U}-{ }^{14} \mathrm{C}\right] \mathrm{aspar}-$ tate gave essentially similar results.

These results suggest that there is no protein synthesis specific for recovery and further investigation is required to discover which of the many proteins synthesized are involved.

The protein synthesis occurring in heated cells or unheated cells incubated in recovery medium may not be required for recovery per se but to maintain an active system for detoxifying tellurite in unheated cells or heated cells that have recovered. However, this would not appear to be the case since, when protein synthesis is prevented by the addition of chloramphenicol or by omitting amino acids from the medium, tellurite resistance and viability of unheated cells are not affected.

We thank Drs J. L. Peel and W. M. Waites for critical reading of the manuscript. 


\section{REFERENCES}

Davis, B. J. \& ORnsteIn, L. (1961). Disc Electrophoresis. Rochester, U.S.A.: Distillation Products Industries.

Emswiler, B. S., Pierson, M. D. \& Shoemaker, S. P. (1976). Sub-lethal heat stress of Vibrio parahaemolyticus. Applied and Environmental Microbiology 32, 792-798.

Gomez, R. F., Blais, K. D., Herrero, A. \& Sinskey, A. J. (1976). Effects of inhibitors of protein, RNA and DNA synthesis on heat-injured Salmonella typhimurium LT2. Journal of General Microbiology 97, 19-27.

Goodman, D. \& Matzura, H. (1971). An improved method of counting radioactive acrylamide gels. Analytical Biochemistry 42, 481-486.

Herbert, D., Phipps, P. J. \& Strange, R. E. (1971). Chemical analysis of microbial cells. IV. Determination of protein - the biuret method. Methods in Microbiology 5B, 244-249.

Hưst, A., Hughes, A., Beare-Rogers, J. L. \& Collins-Thompson, D. L. (1973). Physiological studies on the recovery of salt tolerance by Staphylococcus aureus after sub-lethal heating. Journal of Bacteriology 116, 901-907.

Lowry, O. H., Rosebrough, N. J., FARR, A. L. \&
RANDALL, R. J. (1951). Protein measurement with the Folin phenol reagent. Journal of Biological Chemistry 193, 265-275.

Mandelstam, J. (1958). Turnover of protein in growing and non-growing populations of Escherichia coli. Biochemical Journal 69, 110-119.

PAYNe, J. (1978). Nutrient requirements for the recovery of tellurite resistance by heat-injured Streptococcus faecalis. Journal of General Microbiology 107, 217-222.

Payne, J. \& Morley, J. S. (1976). Recovery of tellurite resistance by heat-injured Streptococcus faecalis. Journal of General Microbiology 94, 421424.

PINE, M. J. (1965). Heterogeneity of protein turnover in Escherichia coli. Biochimica et biophysica acta 104, 439-456.

SchneIDER, W. C. (1945). Phosphorus compounds in animal tissues. I. Extraction and estimation of desoxypentose nucleic acid and of pentose nucleic acid. Journal of Biological Chemistry 161, 293-303.

TomLINS, R. I. \& ORDAL, Z. J. (1971). Requirements of Salmonella typhimurium for recovery from thermal injury. Journal of Bacteriology 105, 512518. 